J. Northw. Atl. Fish. Sci., Vol. 22: 55-69

\title{
Cetacean Habitats in the Alaskan Arctic
}

\author{
Sue E. Moore \\ Science Applications International Corporation, 3990 Old Town Avenue, Suite 105A \\ San Diego, California 92110-2931, USA \\ and
}

Douglas P. DeMaster

National Marine Mammal Laboratory, NMFS/NOAA

7600 Sand Point Way NE, Seattle, Washington 98115, USA

\begin{abstract}
Marine mammals can be used as indicators of environmental productivity because they must feed efficiently and therefore aggregate where prey is plentiful. Three species of cetaceans, bowhead whales (Balaena mysticetus), gray whales (Eschrichtius robustus) and white whales (Delphinapterus leucas) migrate to the Alaskan arctic each year to feed. These species have distinctly different feeding modes and forage at dissimilar trophic levels. Bowhead whales filter zooplankton from the water column, gray whales siphon infaunal crustaceans from the benthos and white whales catch a variety of nekton including crustaceans, cephalopods and fishes.
\end{abstract}

Line transect aerial surveys were conducted over the Alaskan Chukchi and Beaufort seas each late summer and autumn 1982-91. The resulting database, consisting of 634 flights, was post-stratified by survey type and sea state (Beaufort $\leq 04$ ) to provide a database of cetacean sightings made along random transects during good survey conditions. Sightings made during connect and search legs of the survey, and in rough seas were excluded. Post-stratification resulted in a cumulative (1982-91) database of 276754 transect$\mathrm{km}$ of survey effort during which there were 554 bowhead, 608 gray and 831 white whale sightings.

Habitat partitioning and variability in habitat use among cetaceans in offshore areas of northern Alaska is poorly defined. Available data suggest that cetacean distribution and abundance patterns can be quantified on the basis of water depth and surface ice cover, and that these indices can be linked to large-scale oceanographic processes. In summer, mean depth and percent surface ice cover were significantly different $(p<0.001)$ among bowhead $(900 \mathrm{~m}, 52 \% ; n=79)$, gray $(40 \mathrm{~m}, 1 \% ; n=497)$ and white whales $(1314 \mathrm{~m}$, $60 \% ; n=146)$. All pairs were significantly different ( $p<0.003)$, except for bowhead-white whale ice cover $(p<0.13)$. Similarly in autumn, mean depth and percent ice cover were significantly different $(p<0.001)$ among bowhead $(109 \mathrm{~m}, 22 \% ; n=475)$, gray $(38 \mathrm{~m}, 7 \%$; $n=111)$ and white whales $(652 \mathrm{~m}, 52 \% ; n=685)$; all pairs were significantly different $(p<0.001)$. In addition, mean depth and percent ice cover were significantly different $(p<0.001)$ between summer and autumn for bowhead and white whale sightings. Currents are bathymetrically driven, and ice cover influenced by currents and wind, in the Chukchi and Beaufort Seas. The association of cetaceans with specific bathymetric and ice cover regimes provides a foundation for further investigation of inter-specific habitat selection, zones of productivity and insight to the role of cetaceans in Alaskan arctic ecology.

Key words: Alaska, Beaufort Sea, beluga whale, bowhead whale, Chukchi Sea, gray whale, habitats.

\section{Introduction}

Bowhead whales (Balaena mysticetus), gray whales (Eschrichtius robustus) and beluga whales
(Delphinapterus leucas), also called belukha or white whales, migrate annually to arctic waters offshore of northern Alaska. All three species are apex consumers in the short food webs common to polar 
regions. Bowheads feed primarily on zooplankton, gray whales siphon epi- and in-faunal crustaceans from the benthos and white whales prey on a variety of nekton including crustaceans, cephalopods and fishes. Patterns of apex-consumer abundance usually reflect areas of high productivity and prey abundance, which in turn are influenced by the physical environment (Ainley and DeMaster, 1990). While this model has been verified for some mysticete whales in temperate waters (e.g. Kenney and Wishner, 1995), the association of cetaceans with oceanographic features in the arctic has not been examined rigorously.

Extensive observational data on three cetacean stocks (i.e. Bering-Chukchi-Beaufort Sea stock of bowhead whale, eastern North Pacific stock of gray whale, and Beaufort Sea stock of beluga whale) were collected offshore of northern Alaska during aerial surveys in late summer and autumn from 1982-91. Although various descriptive accounts of cetacean distribution and relative abundance were drawn from these data (e.g. Moore, 1992; Moore and Reeves, 1993; Moore and Clarke, 1992, 1993; Moore and Ljungblad, 1984; Moore et al., 1986, 1989, 1993; Clarke et al., 1989, 1993), temporal and spatial scales of analyses varied, impeding comparisons among species. This paper provides an integrated descriptive comparison of cetacean habitats in Alaskan waters for three migratory species that forage at different trophic levels. Inter-specific comparisons of habitat partitioning among these whales may provide new insight to zones of productivity and the role of cetaceans in the Alaskan arctic ecosystem.

\section{Physical Oceanography Offshore Northern Alaska}

Northern Alaska is bounded by the Beaufort and Chukchi seas, which represent distinctly different bathymetric habitats (Fig. 1A). The Chukchi is a broad shallow sea ( $c a 50 \mathrm{~m}$ ) with the major topographic features being Herald and Hanna shoals, and Barrow, Herald and Hanna submarine canyons. Conversely, Beaufort Sea bathymetry is comprised of a narrow continental shelf, demarcated by a steep continental slope that reaches abyssal depths within $70-150 \mathrm{~km}$ of shore. Current flow is bathy-metrically driven in both seas (Fig. 1B). In-flow through Bering Strait bifurcates near $70^{\circ} \mathrm{N}$ latitude; saline Bering Sea Water (BSW: 32.2-33 psu) flows northwest and enters the Arctic basin through Herald Canyon, while the comparatively fresh Alaskan
Coastal Water (ACW: 32.1-32.5 psu) flows northeastward along the coast and enters the Arctic basin through Barrow Canyon (Aagaard, 1987). At Barrow Canyon, the ACW encounters a third major water mass, the resident Chukchi water ( $\mathrm{RCW}$ ), which is comprised of water that has remained on the shelf from the previous winter. Both BSW and $\mathrm{ACW}$ are identifiable on the Beaufort Sea outer shelf (seaward of $50 \mathrm{~m}$ ) as the eastward flowing Beaufort Undercurrent (BU) (Aagaard, 1984). The warm relatively fresh $\mathrm{ACW}$ mixes with ambient surface waters as it moves eastward and is not clearly identifiable east of about $147^{\circ} \mathrm{W}$, while the BSW can be traced to at least $143^{\circ} \mathrm{W}$. Although the northern boundary of the BU is poorly defined, it is thought to extend from 50-2 $500 \mathrm{~m}$ isobaths, a horizontal distance of $60-70 \mathrm{~km}$. Seaward of the BU the Beaufort Gyre flows westward, while current flow along the inner shelf $(<50 \mathrm{~m})$ shifts from eastward to westward with wind forcing (Fissel et al., 1987).

Ice covers the Beaufort and Chukchi seas from December to July. Maximum ice cover extends south to about $57-60^{\circ} \mathrm{N}$ in March; minimum ice cover occurs between $72-75^{\circ} \mathrm{N}$ in September (Niebauer and Schell, 1993). Inter-annual variation in the position of the ice edge can be as great as $400 \mathrm{~km}$, while daily ice drift rates range from about 2 to $9 \mathrm{~km} /$ day. Sharp temperature and salinity fronts are associated with the marginal ice zone (MIZ), a 10-100 km wide dynamic boundary between icecovered and open ocean (Paquette and Bourke, 1981). MIZ deformation in the Chukchi Sea is directly influenced by current flow (Bourke, 1983), while wind stress plays a greater role in ice-edge location in the Beaufort Sea.

\section{Cetacean Migration and Feeding Patterns in the Alaskan Arctic}

The Bering-Chukchi-Beaufort (BCB) stock of bowhead whale (hereafter, bowhead whale), eastern North Pacific (ENP) stock of gray whale (hereafter, gray whale) and Beaufort Sea (BS) and eastern Chukchi Sea (ECS) stocks of beluga whale (hereafter, beluga whale) are the only cetacean species that routinely migrate to and feed in the Alaskan arctic. Bowheads, the only mysticete endemic to arctic and sub-arctic waters, migrate north each spring from wintering areas along the ice edge in the Bering Sea to summering areas in the Canadian Beaufort Sea (Moore and Reeves, 1993). The spring migration proceeds northeast along an open- 

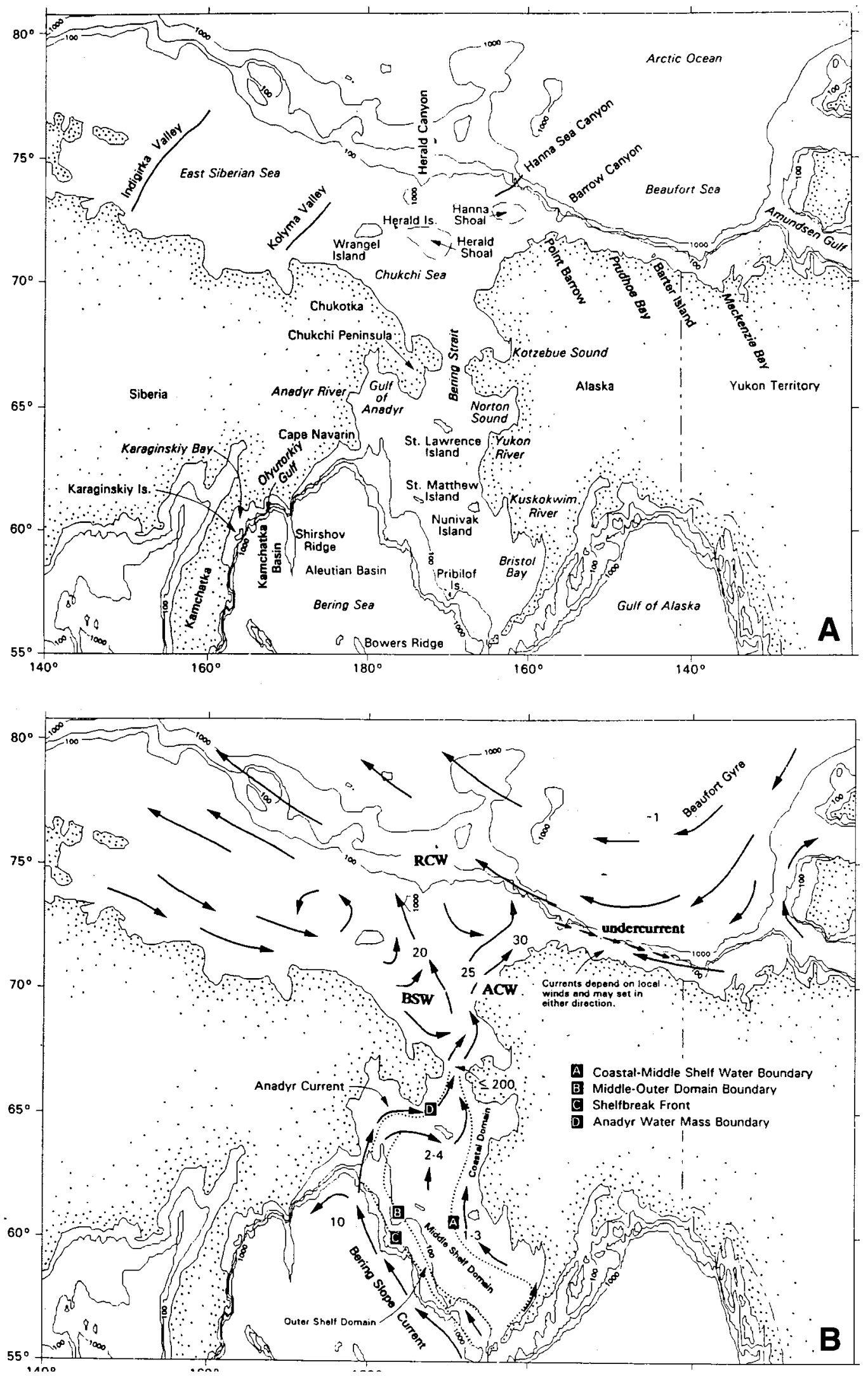

Fig. 1. Bathymetry (A) and surface currents (B) in the Chukchi and Beaufort Seas. Modified from Niebauer and Schell (1993). 
water lead that develops near the Alaskan coast between Pt. Hope and Pt. Barrow. At Pt. Barrow, the whales turn east and make their way through small cracks and leads to the Canadian Beaufort Sea where they feed during summer. Bowheads feed by straining relatively large zooplankton from sea water on long (up to $4.6 \mathrm{~m}$ ) very fine-bristled baleen (Lowry, 1993). Copepods (principally Calanus glacialis and $C$. hyperboredlus) were the dominant prey in 14, and euphausiids (Thysanoessa raschii) the dominant prey in 13, of 35 stomachs analyzed from whales taken by Alaskan Eskimo hunters. In autumn, bowheads migrate west across the Alaskan Beaufort Sea, much closer to shore than in spring. Whales continue to feed, and are themselves hunted, during the autumn migration (Ljungblad et al., 1986; Moore and Clarke, 1992). Stomachs of whales killed in the eastern Alaskan Beaufort Sea are usually full of copepods, while those from whales taken in the western Alaskan Beaufort Sea usually contain euphausiids (Lowry, 1993).

The BCB stock of bowhead whales is currently increasing at approximately $3 \%$ per year and numbers ca 8000 individuals (Zeh et al., 1995). This implies that there were roughly 5800 whales in 1982, and this number increased by $29 \%$ by 1991 . It should also be noted that this stock was hunted by Alaskan aboriginal whalers (Suydam et al., 1995), and was exposed to underwater noise associated with offshore oil and gas exploration activities (Richardson and Malme, 1993), along the northern Alaskan coastline throughout the study period. As the size of this stock has increased between 1982-91, and due to harassment associated with hunting and offshore oil and gas activities, it seems reasonable to expect an increase in the number or range of habitat types used by bowhead whales. However, specific predictions regarding trends in distribution are not possible at this time.

Gray whales migrate to the northern Bering and Chukchi seas to feed from late April through November (Braham, 1984; Moore et al., 1986; Clarke et al., 1989). The migration route essentially follows the coast of North America, with most whales passing through Unimak Pass on the Alaskan Peninsula enroute to northern Alaskan waters. Gray whales are unique among mysticetes in that they suction sediment and benthic prey from the seafloor, then strain the prey on short (to $25 \mathrm{~cm}$ ) coarse-bristled baleen (Nerini, 1984). On the northern feeding ground, benthic amphipods are the dominant prey, with one or two species often comprising $90 \%$ of a whale's stomach contents. Species from six amphipod genera (Ampelisca, Byblis, Haploops, Atylus, Anonyx and Pontoporeia) were dominant in stomachs from 324 whales taken by Russian whalers offshore Chukotka. Suction feeding creates large excavations $\left(2-20 \mathrm{~m}^{2}\right)$ that significantly alter benthic community structure (Nerini and Oliver, 1983; Oliver and Slattery, 1985) and provide foraging opportunities for seabirds, as plumes of mud are brought to the surface (Obst and Hunt, 1990).

The ENP stock of gray whales is currently increasing at approximately $2.5 \%$ per year and includes $c a .22500$ whales. Therefore, this population increased from roughly 16700 individuals to 21400 (or 28\%) during the course of this study (1982-91) and could have been within 30\% of its carrying capacity in the early-1990s (Reilly, 1992). This stock was hunted by the Soviet aboriginal fishery between 1982 and 1991, and exposed to underwater noise from offshore oil and gas activities (Richardson, 1995). Again it is likely that these factors have affected the distribution of gray whales in the Alaskan arctic, but it is not possible to make specific inferences regarding these changes at this time.

The BS beluga stock follows a migration cycle similar to bowheads. In spring, white whales are often seen along the same route as bowheads, while in autumn belugas are generally distributed farther offshore (Moore et al., 1993; Clarke et al., 1993). White whales use teeth to grasp a variety of benthic and pelagic prey; diet varies with season, location, age and body size (Stewart and Stewart, 1989). Although stomach content data are few for white whales in Alaskan waters, the majority of the diet (80\%) is thought to be Arctic cod (Boreogadus saida), with other fishes, cephalopods and shrimps making up the rest (Frost and Lowry, 1984; Seaman et al., 1982). There are no trend data for this stock, but it is assumed to be stable and include over 40000 individuals (Small and DeMaster, 1995). Aboriginal hunting of the BS stock along the northern Alaskan coastline is minimal. Although the ECS beluga stock occupies waters along the norwestern coast of Alaska in July, this population appears to vacate the Chukchi Sea by late summer (Frost et al., 1993), and is not considered further in this paper. 


\section{Methods}

The study area extended north from $65^{\circ} \mathrm{N}$ to $72^{\circ} \mathrm{N}$ latitude, between $169^{\circ} \mathrm{W}$ and $140^{\circ} \mathrm{W}$ longitude. This area was divided into blocks suitable for line transect surveys, with blocks 1-12 comprising the Alaskan Beaufort Sea and blocks 13-25 the Alaskan Chukchi Sea (Fig. 2A). In 1987, surveys to $73^{\circ} \mathrm{N}$ were initiated west of $154^{\circ} \mathrm{W}$ longitude, adding blocks $12 \mathrm{~N}-16 \mathrm{~N}$ to the sampling schedule. Line transect aerial survey was the sampling method for all years 1982-91. Each survey consisted of transect, connect and search legs (Fig. 2B) flown in the aforementioned blocks. The start and end of each transect leg were determined randomly, so sightings made during the survey of transect legs are considered a random sample (Buckland et al., 1993).

Surveys were flown at 152 to $458 \mathrm{~m}$ altitude at 222 to $296 \mathrm{~km} / \mathrm{hr}$ in two types of high-wing aircrafts. Higher altitudes were maintained when weather permitted to increase visual range and reduce the possibility that whales might be disturbed by the aircraft. Each aircraft was equipped with a Global Navigation System 500 that provided a continuous display of position $(0.6 \mathrm{~km} / \mathrm{hr}$ precision, ideally) and was programmable for transect turning points. Data were recorded on a portable computer aboard the aircraft and included entries for: survey leg type, species, number of animals, behavior, ice type and percent surface cover, weather and visibility. Aircraft position and altitude were recorded automatically at each entry, or at 10 minute intervals, via an interface that connected the computer to the aircraft's navigation system and radar altimeter. Surveys were usually curtailed when visibility was $<1 \mathrm{~km}$ or sea state exceeded Beaufort 05 for $>0.5 \mathrm{hr}$. Additional details on survey methods are summarized in Moore and Ljungblad (1984).

\section{Survey Effort and Database}

Cumulative survey effort consisted of 634 flights between 10 July 1982 and 31 October 1991. Summer surveys were flown in July 1982-85, and in August 1982-86 and 1991. Autumn surveys were flown each September and October 1982-91. The cumulative database was post-stratified to include only kilometers of survey on transect legs (hereafter, transect-kilometers: $\mathrm{t}-\mathrm{km}$ ) when sea state was Beaufort $\leq 04$, to provide a baseline of random cetacean sightings (rSI) during good survey condi- tions. This necessarily meant disregarding sightings made during connect and search legs. Analysis of sighting data was done separately for summer and autumn seasons using standard statistical techniques (Zar, 1984).

\section{Results}

\section{Cetacean Distribution and Habitat Associations}

Post-stratification resulted in a cumulative (1982-91) database of $276754 \mathrm{t}-\mathrm{km}$ of survey effort, during which there were sightings of 554 bowhead, 608 gray and 831 white whales, (Table 1; Fig. 3). The distribution of bowhead, gray and white whales was separable on the basis of water depth and surface ice cover in both summer and autumn (Table 2). In summer, bowheads were seen east of $148^{\circ} \mathrm{W}$ in the Alaskan Beaufort Sea, generally seaward of the continental shelf in waters averaging $900 \mathrm{~m}$ deep (Fig. 4). Gray whales were concentrated south of Bering Strait (Chirikov Basin), and along the northwestern Alaskan coast in water averaging $40 \mathrm{~m}$ deep (Fig. 5). White whales were distributed across the Alaskan Beaufort Sea, generally seaward of the continental slope in water averaging $1314 \mathrm{~m}$ deep (Fig. 6). Depth at sightings was significantly different among the three species (ANOVA F $=290, p<0.001$ ), with all pairs significantly different at $p<0.03$.

In autumn, bowhead and white whales were distributed across the Alaskan Beaufort Sea and into the northeastern Chukchi Sea (Fig. 4 and 6). Bowheads were shoreward and white whales seaward of the continental shelf break in water averaging $109 \mathrm{~m}$ and $652 \mathrm{~m}$ deep, respectively. Gray whales were distributed southwest of Pt. Hope, along the northwestern Alaskan coast and in shoal waters west of Pt. Barrow (Fig. 5); average water depth was $38 \mathrm{~m}$ at gray whale sightings. As in summer, depth at sightings was significantly different among the three species (ANOVA F $=107, p<0.001$ ), with all pairs significantly different at $p<0.001$. In addition to difference in mean depth at sightings, the range of depths used by bowhead and beluga whales during the autumn migration were significantly different. That is, the coefficient of variation of depth at sighting for bowhead whales was significantly greater than that for beluga whales in autumn $(t=189, p<0.05)$, but not in summer. This difference may in part be due to the rapid decrease in depth seaward of the shelf break, where beluga whales tend to migrate. 

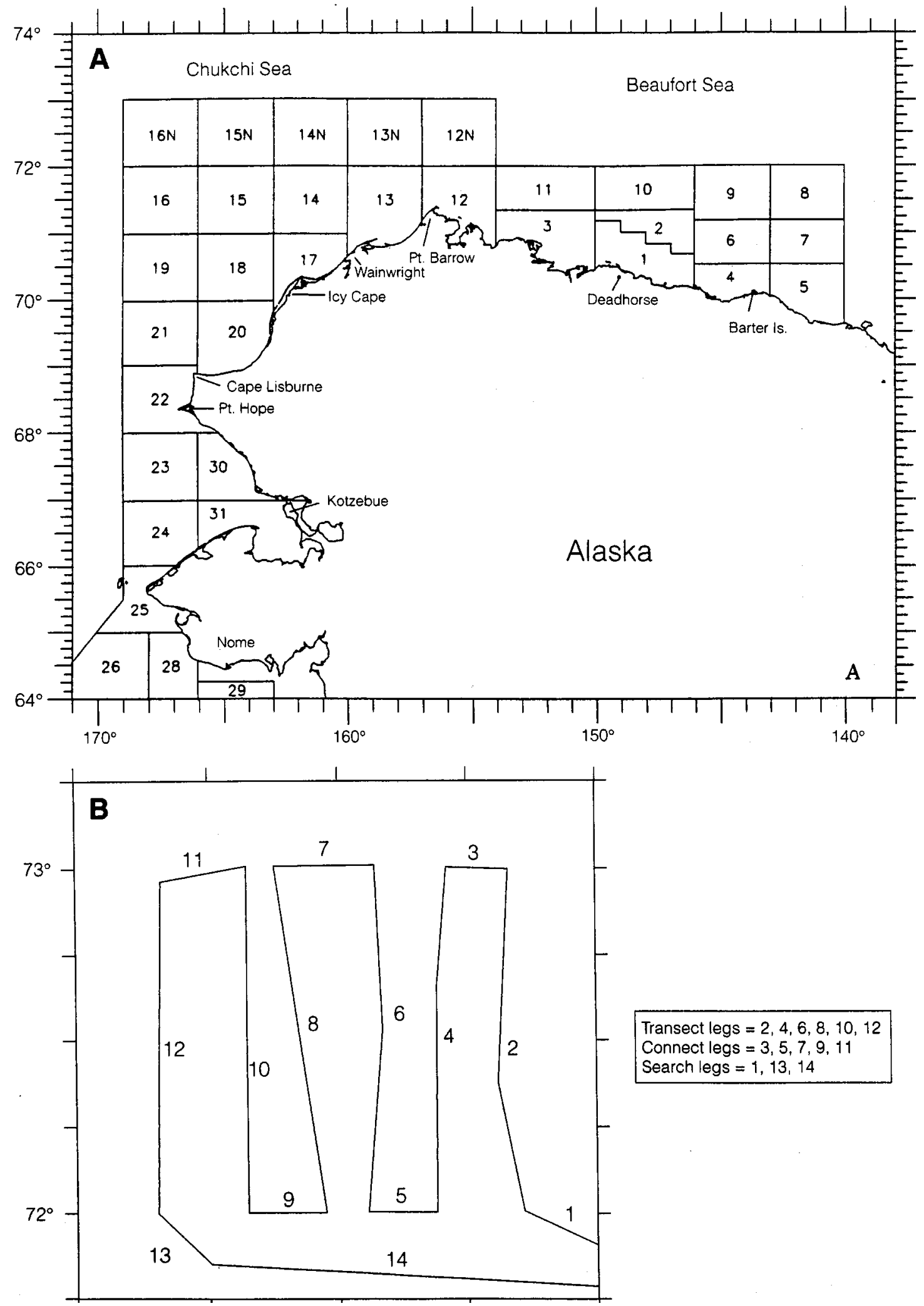

Fig. 2. Aerial survey study area and survey blocks (A) and a typical survey flight track (B) depicting transect, connect and search legs. 
TABLE 1. Cumulative (1982-91) randomized survey effort (t-km) and cetacean sighting database. Summer $=$ July-August; Autumn = September-October. Survey effort $=$ kilometers of transect survey $(\mathrm{t}-\mathrm{km})$, Beaufort $\leq 04$, sightings $=$ random sightings (rSI) only.

\begin{tabular}{lcccc}
\hline \hline Season & $\begin{array}{c}\text { Survey Effort } \\
(\mathrm{t}-\mathrm{km})\end{array}$ & $\begin{array}{c}\text { Sightings (rSI) } \\
\text { Bowhead Whales }\end{array}$ & Gray Whales & White Whales \\
\hline Summer & 60728 & 79 & 497 & 146 \\
Autumn & 216026 & 475 & 111 & 685 \\
Total & 276754 & 554 & 608 & 831 \\
\hline
\end{tabular}

The three species were also associated with distinctly different surface ice cover habitat. In summer, ice cover averaged $52 \%$ at bowhead sightings, $1 \%$ at gray whale sightings and $60 \%$ at white whale sightings (Table 2). Ice cover was significantly different among the three species (ANOVA $F=558$, $p<0.001$ ), with all pairs significantly different at $p<0.001$, except for bowhead-white whale comparison $(p<0.13)$. In autumn, ice cover averaged $22 \%$ at bowhead sightings, $7 \%$ at gray whale sightings and 52\% at beluga sightings. Again, ice cover was significantly different among species (ANOVA F $=$ $146, p<0.001$ ), with all pairs significantly different at $p<0.001$.

Bowhead and white whales exhibited seasonal differences in habitat use, but gray whales did not. Depth at sightings was significantly different between summer and autumn for bowhead $(t=439$, $p<0.001)$ and white whales $(t=262, p<0.001)$. In both species, the shift was from use of deeper water during summer to shallower water during autumn (Table 2). Ice cover at sightings was also significantly different between summer and autumn for bowhead $(t=52, p<0.001)$ and white whales $(t=$ $12, p<0.001)$. In both cases, the shift was from association with heavier ice cover in summer to lighter ice cover in autumn. The shift in ice habitat may simply reflect a move towards shore to shallower water, as ice conditions are generally lighter near shore compared to offshore during autumn.

\section{Discussion}

Bowhead, gray and beluga whales occupy dissimilar bathymetric and ice cover habitats offshore northern Alaska. Among the three species, white whales were consistently associated with the deepest water and heaviest ice cover, gray whales with the shallowest water and lightest ice cover, with bowhead depth and ice cover habitat intermediate to the two. These differences in habitat selection likely reflect distinct feeding modes and preferred prey among the three species. All three species rely on finding dense prey concentrations. In summer, bowheads are often seen near frontal features that can concentrate zooplankton in the Canadian Beaufort Sea (Bradstreet et al., 1987; Wursig and Clark, 1993). In one case, feeding bowheads were directly associated with a dense $5 \mathrm{~m} \times 8 \mathrm{~km}$ patch of zooplankton that contained the euphausiid T. raschii, which occurred at a sharp salinity (proxy density) gradient at about $30 \mathrm{~m}$ depth offshore the Chukotka peninsula (Moore et al., 1995). Gray whale feeding excavations indicated they repeatedly suction prey from dense patches of tube-building amphipods (Oliver and Slattery, 1985). Gray whale feeding areas offshore of northern Alaska are characterized by low species diversity, high biomass, and the highest secondary production rates reported for any extensive benthic community (Highsmith and Coyle, 1990; 1992). Little is known about white whale foraging in Alaskan waters, but dense prey concentrations appear important in areas where feeding has been studied (Hazard, 1988). In the Canadian High Arctic, large schools of Arctic cod were preyed upon by hundreds of belugas, to the point of being driven ashore (Welch et al., 1993). Although the distribution of Arctic cod offshore Alaska is unknown, cod distribution elsewhere appears to correspond roughly with the distribution of large zooplankters (Crawford and Jorgenson, 1990). It is postulated that the ice edge is a site of high fish production due to local oceanic upwelling (Dunbar, 1981), and birds and marine mammals presumably aggregate there due to enhanced feeding opportunities (Bradstreet and Cross, 1982).

The Alaskan Arctic is a dynamic ecosystem. The influx of North Pacific water (ACW + BSW) through Bering Strait defines the character of the Chukchi Sea, and strongly influences the hydrography 

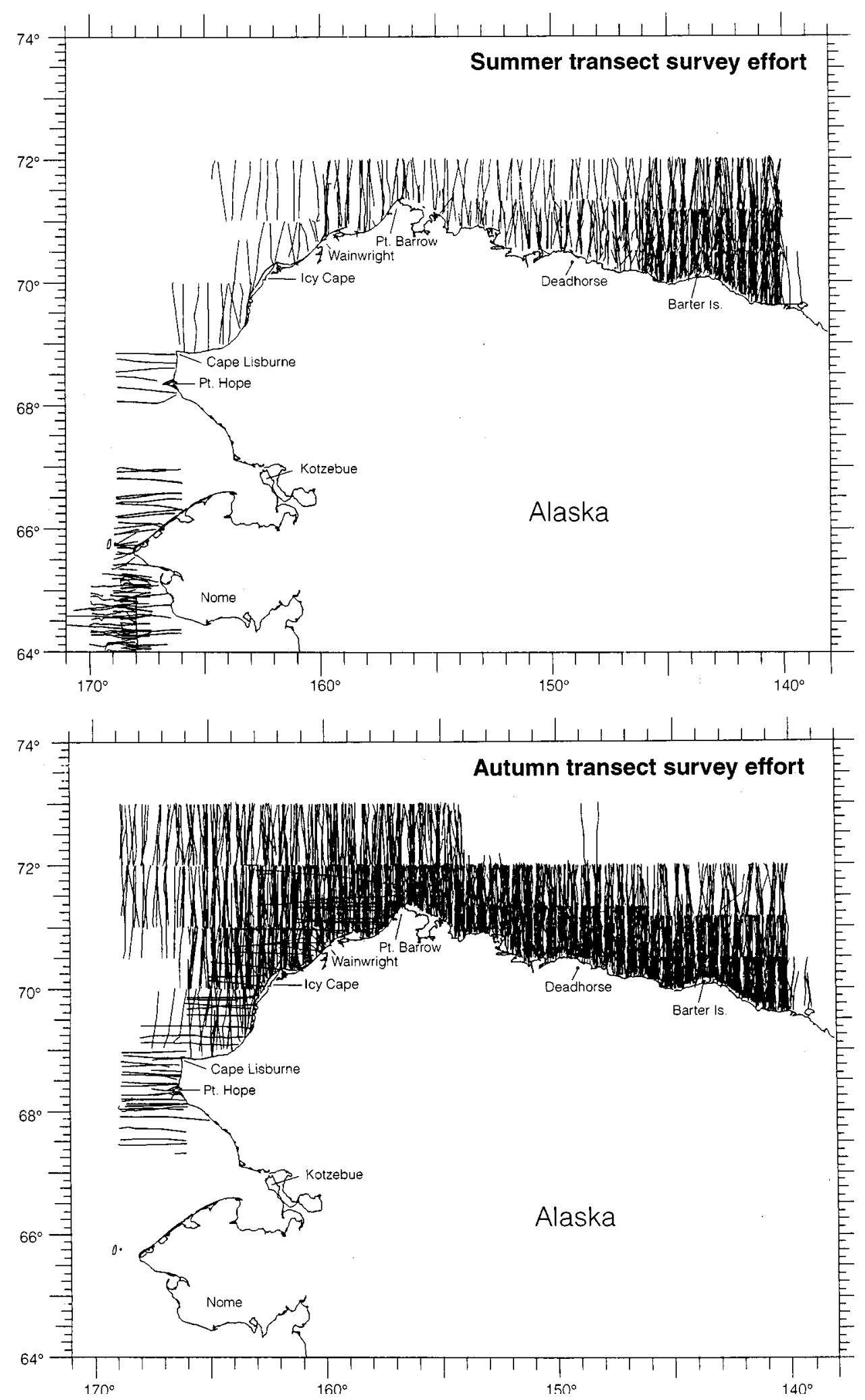

Fig. 3. Summer (July-August) and autumn (September-October) survey effort in offshore areas of northern Alaska, 1982-91. Only random-transect survey legs are plotted $(\mathrm{t}-\mathrm{km})$. 
TABLE 2. Descriptive statistics for water depth and ice cover at bowhead, gray and white whale sightings offshore northern Alaska in summer (July-August) and autumn (SeptemberOctober).

\begin{tabular}{|c|c|c|c|c|c|c|c|c|}
\hline & \multicolumn{4}{|c|}{ Depth (m) } & \multicolumn{4}{|c|}{ Ice $(\%)$} \\
\hline & $\mathrm{X}$ & $\mathrm{sd}$ & SE & $\mathrm{CV}$ & $\bar{X}$ & $\mathrm{sd}$ & SE & $\mathrm{CV}$ \\
\hline & \multicolumn{8}{|c|}{ Summer } \\
\hline $\begin{array}{l}\text { Bowhead Whale } \\
(n=79)\end{array}$ & 900 & 861 & 96.87 & 0.96 & 52 & 36 & 4.09 & 0.69 \\
\hline $\begin{array}{l}\text { Gray Whale } \\
(n=497)\end{array}$ & 40 & 7 & 0.32 & 0.18 & 1 & 5 & 0.23 & 5.00 \\
\hline \multirow[t]{2}{*}{$\begin{array}{l}\text { White Whale } \\
\quad(n=146)\end{array}$} & 1314 & 1166 & 96.51 & 0.89 & 60 & 38 & 3.15 & 0.63 \\
\hline & \multicolumn{8}{|c|}{ Autumn } \\
\hline $\begin{array}{l}\text { Bowhead Whale } \\
(n=475)\end{array}$ & 109 & 332 & 15.20 & 3.05 & 22 & 35 & 1.61 & 1.59 \\
\hline $\begin{array}{l}\text { Gray Whale } \\
(n=111)\end{array}$ & 38 & 15 & 1.40 & 0.39 & 7 & 21 & 1.95 & 3.00 \\
\hline $\begin{array}{l}\text { White Whale } \\
(n=685)\end{array}$ & 652 & 881 & 33.58 & 1.35 & 52 & 37 & 1.41 & 0.71 \\
\hline
\end{tabular}

of the Beaufort Sea. The inflow cycle peaks in June and January, and displays strong wind-dependent inter-annual variation (Coachman and Aagaard, 1988; Aagaard et al., 1985). The eastward-flowing $\mathrm{BU}$ provides an important dispersal and transport mechanism from the northern Bering Sea. Because currents are bathymetrically channeled (i.e. extend from the sea floor to the surface), the association of each species with specific water depths provides a means to infer the current regime/water mass occupied (see Fig. 1B). For example, bowheads and white whales were associated with the Beaufort Undercurrent (BU) in summer. In autumn, bowheads moved into shallow shelf waters, while white whales remained in habitat associated with the BU and, presumably, the Beaufort Gyre. In the Chukchi Sea, bowhead and white whales were associated with Alaskan Coastal Water (ACW) and Beaufort Sea Water (BSW) channeled by Barrow and Herald Canyons, while gray whales were seen in shoal areas where secondary productivity is strongly influenced by carbon transport from ACW and BSW (Grebmeier et al., 1988; 1989).

Patterns of seabird distribution and abundance have been linked to water masses and their constituent prey in the northern Bering Sea (Elphick and Hunt, 1993). Although similar relationships have not been directly investigated for cetaceans, whale association with bathymetric and ice regimes (i.e. proxy water mass delimiters) provides an avenue for speculation. Bowhead whales feed primarily on advected zooplankton (euphausiids) in the Chukchi and western Beaufort Sea, and on copepods that overwinter in the eastern Beaufort Sea. Bowhead occupation of BU water in summer may reflect whales foraging on copepods still at depth, while movement to shelf water in autumn may provide the greatest opportunity to encounter prey advected there from the Bering Sea. White whales remain associated with ice, and relatively deep water, throughout the summer and autumn. This may reflect their penchant for feeding on ice-associated Arctic cod. It is important to note that only a portion of the large BS white whale stock was likely sampled during this study, so habitat associations are probably not fully described here.

Gray whales, unlike bowhead and beluga whales, occupied virtually the same habitat throughout summer and autumn. The shallow shoal and coastal areas offshore of Alaska provide habitat rich in gray whale prey and there is little reason for whales to abandon it prior to winter onset. Indeed, gray whales differ markedly from bowhead and beluga whales in that their foraging excavations appear to structure the benthic community upon which they feed (Oliver and Slattery, 1985). In this 

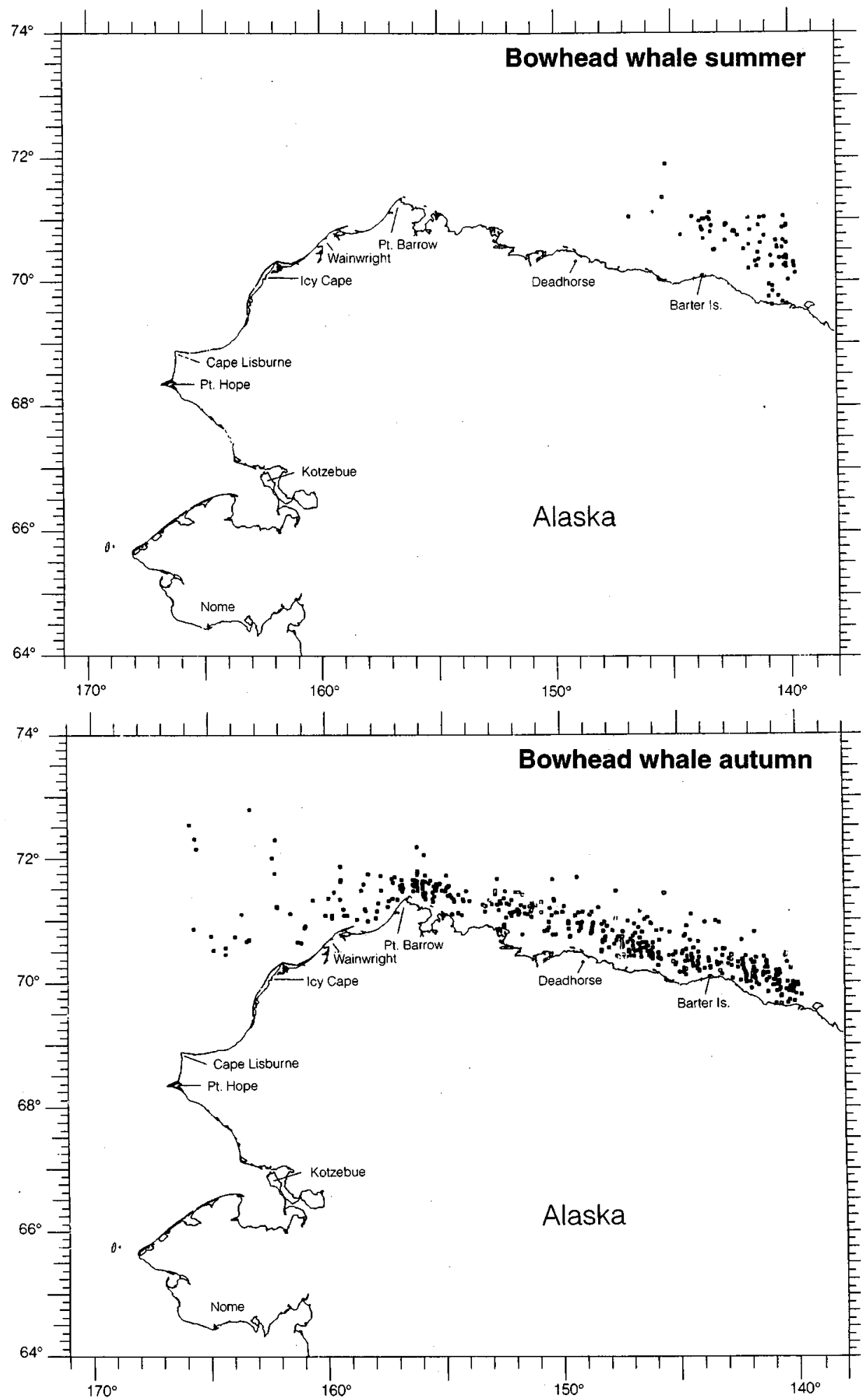

Fig. 4. Bowhead whale distribution in the summer (July-August) and autumn (September-October). Random-transect sightings (rSI) only; sample sizes are listed in Table 2. 
MOORE and DeMASTER: Cetacean Habitats in the Alaskan Arctic
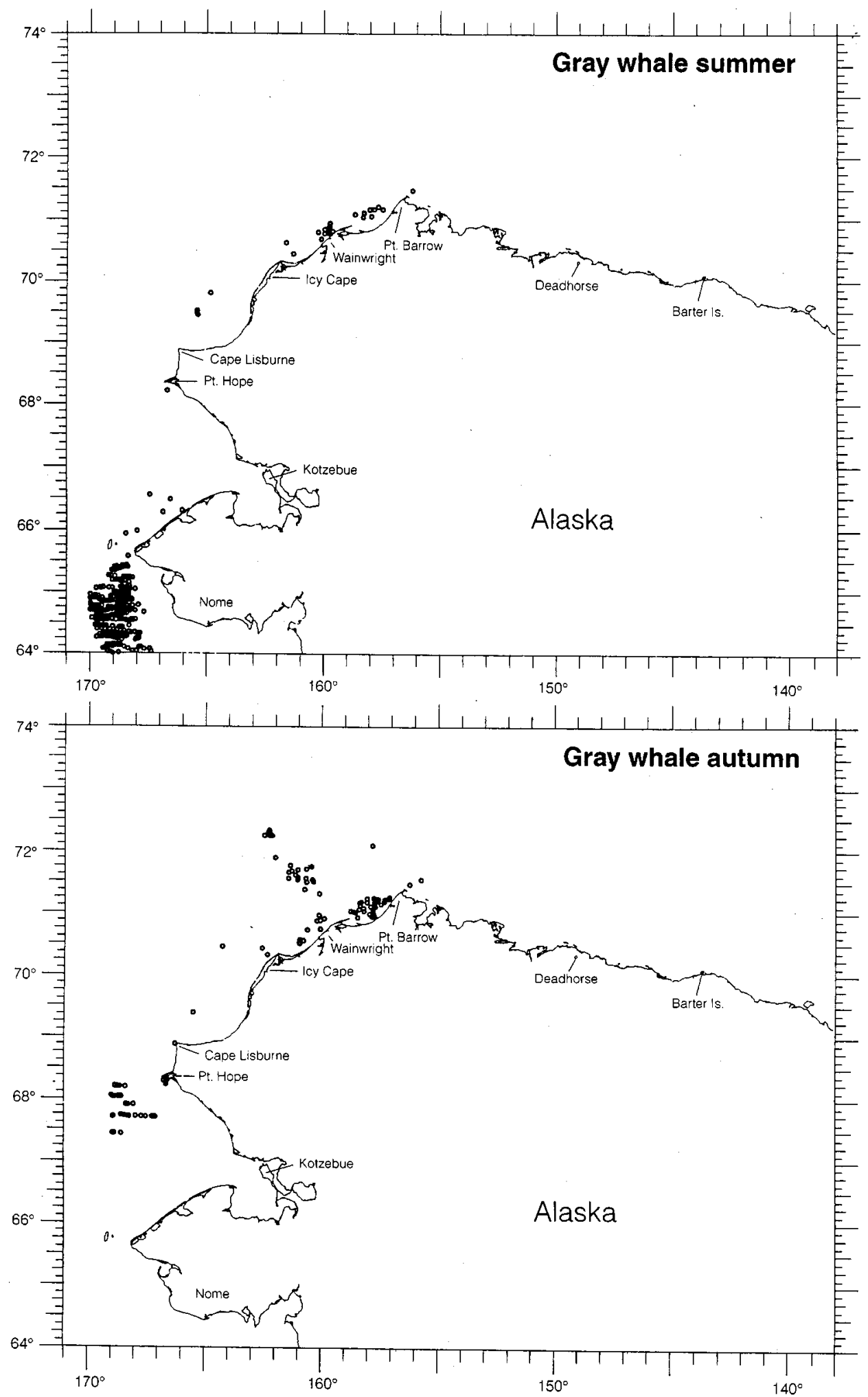

Fig. 5. Gray whale distribution in the summer (July-August) and autumn (SeptemberOctober). Random-transect sightings (rSI) only; sample sizes are listed in Table 2. 

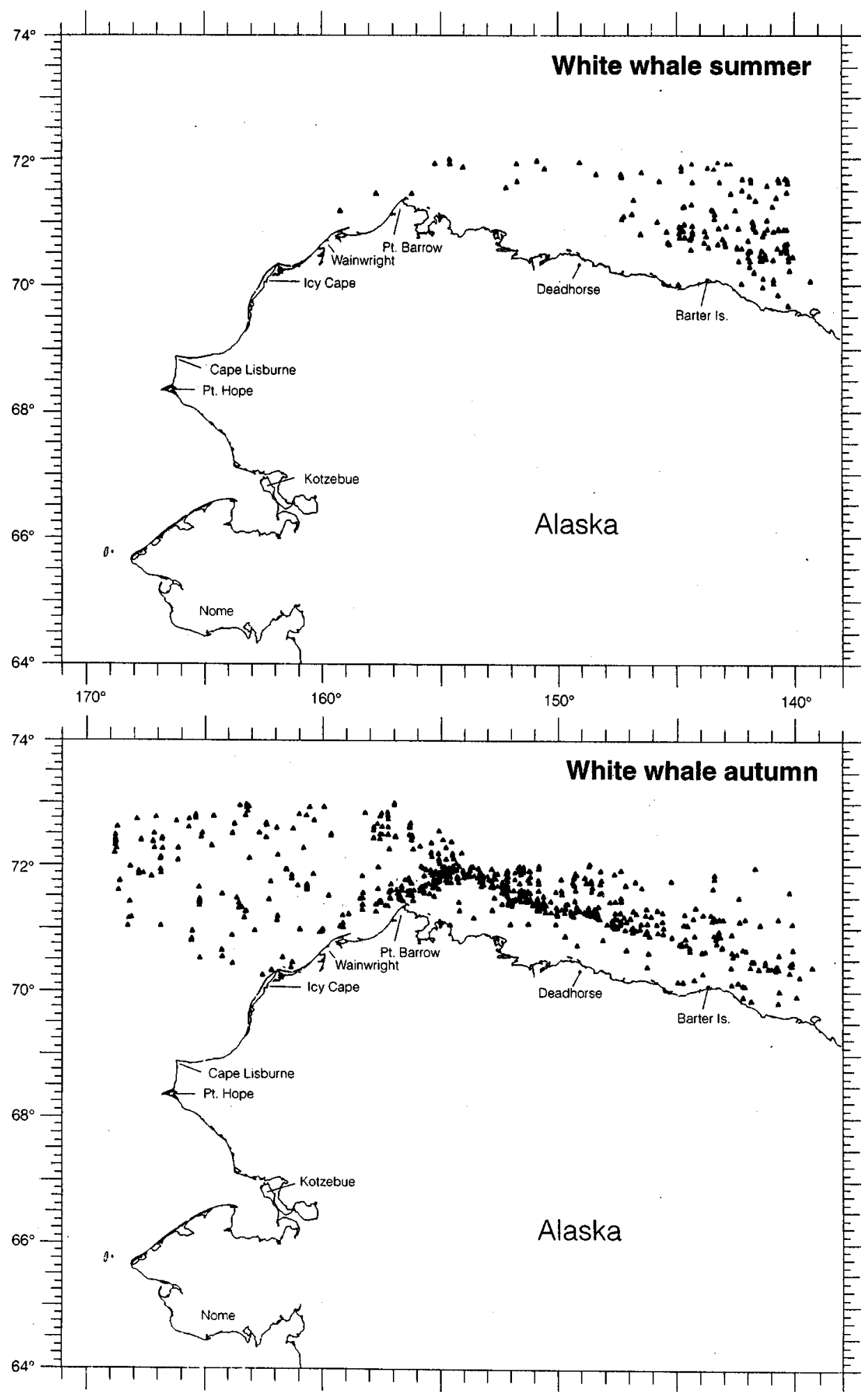

Fig. 6. White whale distribution in the summer (July-August) and autumn (September-October). Random-transect sightings (rSI) only; sample sizes are listed in Table 2. 
way, gray whales participate in a dynamic feedbackloop, recently termed 'niche construction' (OdlingSmee et al., 1996), whereby their own activities serve to shape their niche through alteration of the benthos.

The three cetacean stocks considered here were exposed to human hunting pressure and underwater noise associated offshore industrial activities throughout the ten-year study period. During this time, both the BCB bowhead and ENP gray whale stocks increased in number. While these factors likely affect distribution and habitat selection for each stock, specific relationships between extrinsic and intrinsic influences remain unclear. For example, both bowhead and gray whales have demonstrated avoidance of underwater noise from drilling platforms and seismic survey vessels at ranges of 5-10 km, however, behavioral reactions varied widely among observations, and whales were sometimes seen within a few hundred meters of such activities (Richardson, 1995). Similarly, reaction of beluga whales to anthropogenic underwater noise varies from great tolerance to extreme sensitivity, seemingly dependent upon whale activities and experience (Richardson, 1995). Finally, although bowhead whales have been observed to flee Eskimo hunting boats (Richardson, 1995), the distances of whale sightings from shore within the whaling area near Barrow, Alaska were not significantly different among years 1982-89 (Moore and Clarke, 1992), suggesting no sustained response by bowheads to local hunting pressure during that period.

Further investigation of habitat partitioning and variability in habitat use among the three cetacean stocks considered here is ongoing (Moore, 1997). One approach to an improved understanding of cetacean habitat selection offshore of Alaska is to integrate sighting data with extant information on hydrography and ice conditions. Unfortunately, post-survey correlation of oceanographic and cetacean sighting data sets over the 1982-91 period has proven difficult at best due to differences in spacial and temporal sampling scales. While analysis of extant data can provide an integrated approach to habitat description, a dynamic model of cetacean habitat utilization patterns in the Alaskan Arctic will be achieved only when oceanographic data can be collected in direct association with sighting records.

\section{Acknowledgements}

We thank Janet Clarke, Science Applications Interantional Corporation (SAIC) for her skill in data management and for providing helpful comments on preliminary drafts of this manuscript, Cindy Tynan for presenting this work at the NAFO/ ICES Symposium, two anonymous referees and J. Sigurjonsson for helpful suggestions on the final manuscript. This research was funded by the Minerals Management Service, Alaska Outer Continental Shelf Region, United States Department of the Interior.

\section{References}

AAGAARD, K. 1984. The Beaufort undercurrent. In: The Alaskan Beaufort Sea: Ecosystems and Environments, P. W. Barnes, D. M. Schell and E. Reimnitz (eds.). Academic Press, Inc., p. 47-71.

1987. Physical oceanography of the Chukchi Sea: an overview. OCS Env. Assess. Program: Chukchi Sea Information Update, June 1987, 3-10.

AAGAARD, K., A. T. ROACH, and J. D. SCHUMACHER. 1985. On the wind-driven variability of the flow through Bering Strait. J. Geophys. Res., 90: 72137221.

AINLEY, D. G. and D. P. DeMASTER. 1990. The upper trophic levels in polar marine ecosystems. In: Polar Oceanography Part B: Chemistry, Biology and Geology, W.O. Smith Jr. (ed.), Academic Press, Inc., p. 599-630.

BOURKE, R. H. 1983. Currents, fronts and fine structure in the marginal ice zone of the Chukchi Sea. Polar Record, 21, 135: 569-575.

BRADSTREET, M. S. W. and W. E. CROSS. 1982. Trophic relationships at high Arctic ice edges. Arctic, 35: 1-12.

BRADSTREET, M. S. W., D. H. THOMSON, and D. B. FISSEL. 1987. Zooplankton and bowhead whale feeding in the Canadian Beaufort Sea, 1986. Report by LGL Limited to Canadian Department of Indian Affairs and Northern Development, Ottawa, Ontario, Canada, 204 p.

BRAHAM, H. W. 1984. Distribution and migration of gray whales in Alaska. In: The Gray Whale, M. L. Jones, S. L. Swartz, and S. Leatherwood (eds.) Academic Press, Inc., p. 249-266.

BUCKLAND, S. T., D. R. ANDERSON, K. P. BURNHAM and J. L. LAAKE. 1993. Distance Sampling. Chapman \& Hall, New York, 446 p.

CLARKE, J. T., S. E. MOORE, and M. M. JOHNSON. 1993. Observations on beluga fall migration in the Alaskan Beaufort Sea, 1982-87, and northeastern Chukchi Sea, 1982-91. Rep. Int. Whal. Comm., 43: 387-396.

CLARKE, J. T., S. E. MOORE, and D. K. LJUNGBLAD. 
1989. Observations on gray whale (Eschrichtius robustus) utilization patterns in the northeastern Chukchi Sea, July-October 1982-1987. Can. J. Zool., 67: 2 646-2 654.

COACHMAN, L. K., and K. AAGAARD. 1988. Transports through Bering Strait: annual and interannual variability. J. Geophys. Res., 93(C12): 15 53515539.

CRAWFORD, R. and J. JORGENSON. 1990. Density distribution of fish in the presence of whales at the Admiralty Inlet Landfast Ice Edge. Arctic, 43(3): 215-222.

DUNBAR, M. J. 1981. Physical causes and biological significance of polynyas and other open water in sea ice. In: Polynyas in the Canadian Arctic, I. Sterling and H. Cleator (eds.). Canadian Wildlife Service Occasional Paper, No. 45: 29-43.

ELPHICK, C. S. and G. L. HUNT. 1993. Variations in the distributions of marine birds with water mass in the northern Bering Sea. The Condor, 95: 33-44.

FISSEL, D. B., J. R. MARKO, J. R. BIRCH, G. A. BORSTAD, D. N. TRUAX, and R. KERR. 1987. Water mass distribution. In: Importance of the eastern Alaskan Beaufort Sea to feeding bowhead whales, 1985-86. W. J. Richardson (ed.). OCS Study MMS-87-0037. Final Report to the U.S. Minerals Management Service, Alaska OCS Region, prepared by LGL Ecological Research Associates, Inc., p. 11-134.

FROST, K. J., L. F. LOWRY, AND G. CARROLL. 1993. Beluga whale and spotted seal use of a coastal lagoon system in the northeastern Chukchi Sea. Arctic, 46(1): 8-16.

FROST, K. J. and L. F. LOWRY. 1984. Trophic relationships of vertebrate consumers in the Alaskan Beaufort Sea. In: The Alaskan Beaufort Sea: Ecosystems and Environments, P. W. Barnes, D. M. Schell, and E. Reimnitz (eds.). Academic Press Inc., p. 381-401.

GREBMEIER, J. M., H. M. FEDER, and C. P. McROY. 1989. Pelagic-benthic coupling on the shelf of the northern Bering and Chukchi Seas. II. Benthic community structure. Mar. Ecol. Prog. Ser., 51: 253-268.

GREBMEIER, J. M., C. P. McROY, and H. M. FEDER. 1988. Pelagic-benthic coupling on the shelf of the northern Bering and Chukchi Seas. I. Food supply source and benthic biomass. Mar. Ecol. Prog. Ser., 48: $57-67$.

HAZARD, K. 1988. Beluga whale, Delphinapterus leucas. In: Selected marine mammals of Alaska. J. W. Lentfer (ed.), Marine Mammal Commission, p. 195-235.

HIGHSMITH, R. C. and K. O. COYLE. 1990. High productivity of northern Bering Sea benthic amphipods. Nature, 344(6269): 862-864.

1992. Productivity of arctic amphipods relative to gray whale energy requirements. Mar. Ecol. Prog. Ser., 83: 141-150.

KENNEY, R. D. and K. F. WISHNER. 1995. The south channel ocean productivity experiment. Cont. Shelf Res., 15 (4/5): 373-384.

LJUNGBLAD, D. K., S. E. MOORE, and J. T. CLARKE, 1986. Assessment of bowhead whale (Balaena mysticetus) feeding patterns in the Alaskan Beaufort and northeastern Chukchi Seas via aerial surveys, Fall 1979-84. Rep. Int. Whal. Comm., 36: $265-272$.

LOWRY, L. F. 1993. Foods and feeding ecology. In: The Bowhead Whale, J. J. Burns, J. Montague, and C. Cowles (eds.) Society for Marine Mammalogy, Special Publication No. 2: 201-238.

MOORE, S. E. 1997. Cetacean Habitats in the Alaskan Arctic. Ph. D. dissertation. Scripps Institution of Oceanography, UCSD, San Diego, CA, 318 p.

MOORE, S.E. 1992. Summer records of bowhead whales in the northeastern Chukchi Sea. Arctic, 45(4): 398-400.

MOORE, S. E., and J. T. CLARKE. 1993. Bowhead whale autumn distribution and relative abundance in relation to oil and gas lease areas in the northeastern Chukchi Sea. Polar Rec., 29(170): 209-214.

MOORE, S. E. and J. T. CLARKE. 1992. Patterns of bowhead whale distribution and abundance near Barrow, Alaska, in fall 1982-1989. Mar. Mamm. Sci., 8(1): 27-36.

MOORE, S. E. and D. K. LJUNGBLAD. 1984. Gray whales in the Beaufort, Chukchi and Bering seas: distribution sound production. In: The Gray Whale, M. L. Jones, S. L. Swartz and S. Leatherwood (eds.), Academic Press, Inc., p. 543-559.

MOORE, S. E. and R. R. REEVES. 1993. Distribution and movement. In: The Bowhead Whale, J. J. Burns, J. J. Montague, and C. J. Cowles (eds.) Society for Marine Mammalogy, Special Publication No. 2: 313-386.

MOORE, S. E., J. T. CLARKE, and M. M. JOHNSON. 1993. Beluga distribution and movements offshore northern Alaska in spring and summer, 1980-84. Rep. Int. Whal. Comm., 43: 375-386.

MOORE, S. E., J. T. CLARKE, and D. K. LJUNGBLAD. 1989. Bowhead whale (Balaena mysticetus) spatial and temporal distribution in the central Beaufort Sea during late summer and early fall 1979-86. Rep. Int. Whal. Comm., 39: 283-290.

MOORE, S. E., D. K. LJUNGBLAD, and D. R. VanSCHOIK. 1986. Annual patterns of gray whale (Eschrichtius robustus) distribution, abundance and behavior in the northern Bering and eastern Chukchi Seas, July 1980-1983. Rep. Int. Whal. Comm., Special Issue 8: 231-242.

MOORE, S. E., J. C. GEORGE, K. O. COYLE, and T. J. WEINGARTNER. 1995. Bowhead whales along the Chukotka coast in autumn. Arctic, 48(2): 155-160.

NERINI, M. K. 1984. A review of gray whale (Eschrichtius robustus) feeding ecology. In: The Gray Whale, M. L. Jones, S. L. Swartz, and S. Leatherwood (eds.), Academic Press, Inc., p. 423-450. 
NERINI, M. K. and J. S. OLIVER. 1983. Gray whales and the structure of the Bering Sea benthos. Oecologia, 59: 224-225.

NIEBAUER, H. J. and D. M. SCHELL. 1993. Physical environment of the Bering Sea population. In: The Bowhead Whale, J. J. Burns, J. J. Montague, and C. J. Cowles (eds.). Society for Marine Mammalogy, Special Publication No. 2: 23-43.

OBST, B. S. and G. L. HUNT, Jr. 1990. Marine birds feed at gray whale mud plumes in the Bering Sea. The Auk, 107: 678-688.

ODLING-SMEE, F. J., K. N. LALAND, and M. W. FELDMAN. 1996. Niche Construction. Am. Nat., 147(4): 641-648.

OLIVER, J. S. and P. N. SLATTERY. 1985. Destruction and opportunity on the sea floor: effects of gray whale feeding. Ecology, 66(6): 1965-75.

PAQUETTE, R. G. and R. H. BOURKE. 1981. Ocean circulation and fronts as related to ice melt-back in the Chukchi Sea. J. Geophys. Res., 86(C5): 42154230 .

REILLY, S. B. 1992. Population biology and status of eastern Pacific gray whales: recent developments. In: Wildlife 2001: Populations, D. R. McCullough and R. H. Barrett (eds.) Elsevier Applied Science, p. 1062-1074.

RICHARDSON, W. J. 1995. Documented disturbance reactions. In: Marine Mammals and Noise, W. J. Richardson, C. R. Greene, Jr., C. I. Malme, and D. H. Thomson (eds.) Academic Press, Inc., p. 241324.

RICHARDSON, W. J. and C. I. MALME. 1993. Man- made noise and behavioral responses. In: The Bowhead Whale, J. J. Burns, J. J. Montague, and C. J. Cowles (eds.) Society for Marine Mammalogy, Special Publication No. 2: 631-700.

SEAMAN, G. A., L. F. LOWRY, and K. J. FROST. 1982. Foods of belukha whales (Delphinapterus leucas) in western Alaska. Cetology, 4: 1-19.

SMALL, R. J. and D. P. DeMASTER. 1995. Alaska Marine Mammal Stock Assessments 1995. NOAA Tech. Mem., NMFS-AFSC-57, 93 p.

STEWART, B. E. and R. E. A. STEWART. 1989. Delphinapterus leucas. Mammalian Species, Am. Soc. of Mamm., 336: 1-8.

SUYDAM, R. S., R. P. ANGLISS, J. C. GEORGE, S. R. BRAUND, and D. P. DeMASTER. 1995. Revised data on the subsistence harvest of bowhead whales (Balaena mysticetus) by Alaska Eskimos, 19731993. Rep. Int. Whal. Comm., 45: 335-338.

WELCH, H. E., R. E. CRAWFORD, and H. HOP. 1993. Occurrence of arctic cod (Boreogadus saida) schools and their vulnerability to predation in the Canadian High Arctic. Arctic, 46(4): 331-339.

WURSIG, B. and C. CLARK. 1993. Behavior. In: The Bowhead Whale, J. J. Burns, J. J. Montague, and C. J. Cowles (eds.). Society for Marine Mammals, Special Publication No. 2: 157-199.

ZAR, J. H. 1984. Biostatistical Analysis. 2nd Ed. Prentice Hall Inc., New Jersey, 718 p.

ZEH, J. E. J. C. GEORGE, and R. SUYDAM. 1995. Population size and rate of increase, 1978-1993, of bowhead whales, Balaena mysticetus. Rep. Int. Whal. Comm., 45: 339-344. 